\title{
O CONTROLE CONCENTRADO DE CONSTITUCIONALIDADE E A DEFESA DE INTERESSES CORPORATIVOS: análise das ADIs no
}

\author{
período de 2013 a 10 de novembro de 2015
}

\author{
Adriano Ferreira de Oliveira ${ }^{308}$ \\ Felipe de Almeida Campos ${ }^{309}$ \\ Renato Horta Rezende 310 \\ Virgílio Queiroz, de Paula ${ }^{311}$ \\ Wagner Facundo Fantoni ${ }^{312}$
}

Recebido em: 24/01/2016

Aprovado em: 15/08/2016

\begin{abstract}
RESUMO
O controle de constitucionalidade vem sendo justificado no meio acadêmico como meio a garantir os direitos das minorias contra interesses das maiorias expressas em leis violadoras de direitos fundamentais, porém, atualmente, as decisões proferidas pelo STF, em sede de controle concentrado de constitucionalidade, não vêm guardando correspondência com a teoria garantidora mencionada, pois repercutem interesses corporativos de grupos privilegiados, por vezes alheios aos direitos fundamentais. Identificado o problema, partiu-se para a hipótese de que o atual desenho constitucional dirigido ao controle de constitucionalidade promove e está direcionado, de fato, a proteção de direitos corporativistas e, tal fato, repercute nas decisões proferidas pelo STF. Para desenvolver a hipótese foram realizados estudos bibliográficos sobre o tema, inicialmente descrendo a origem das matrizes do controle de constitucionalidade e seu desenvolvimento no Brasil, passando a apresentação das teorias procedimentalistas e substancialistas do controle de constitucionalidade e as espécies de ações diretas dirigidas ao STF no controle concentrado e abstrato de Leis ou atos normativos. Com o objetivo de avaliar a hipótese também foram levantados e analisados dados informativos contidos no site oficial do STF no período compreendido entre 2013 a 10 de novembro de 2015, sendo, ao final, confirmado que, hoje, o desenho do controle
\end{abstract}

\footnotetext{
${ }^{308}$ Mestrando do PPGD da Universidade FUMEC, Belo Horizonte, Minas Gerais. Servidor público. Endereço eletrônico: adrferoli@hotmail.com.

${ }^{309}$ Mestrando do PPGD da Universidade FUMEC, Belo Horizonte, Minas Gerais. Assessor jurídico. Endereço eletrônico: feacamposadv@gmail.com.

${ }^{310}$ Mestrando do PPGD da Universidade FUMEC, Belo Horizonte, Minas Gerais. Advogado. Endereço eletrônico: renatohorta@yahoo.com.br.

${ }^{311}$ Mestrando do PPGD da Universidade FUMEC, Belo Horizonte, Minas Gerais. Advogado. Endereço eletrônico: virgilioadvogado@gmail.com.

${ }^{312}$ Mestrando do PPGD da Universidade FUMEC, Contagem, Minas Gerais. Servidor público.
} 
concentrado de constitucionalidade serve a interesses corporativistas de grupos determinados.

Palavras-chave: Controles concentrado. Interesses corporativistas. Teoria substancialista.

\section{INTRODUÇÃO}

O controle concentrado de constitucionalidade consagrado na Constituição da República Federativa do Brasil, de 05 de outubro de 1988, apesar de ter balizas próprias, possui origem remota na matriz austríaca criada por Hans Kelsen, que concede ao Poder Judiciário, por meio de órgão próprio e específico, denominado Corte Constitucional, a função de "legislador negativo" capaz de eliminar normas jurídicas inconstitucionais (FERNANDES, 2013, p. 911).

O sistema de controle concentrado e abstrato de constitucionalidade de normas jurídicas foi sendo desenvolvido paulatinamente no Brasil alcançando na atual Constituição maior evidência e destaque em virtude de seus efeitos erga omnes e ex tunc ${ }^{313}$, assim como em razão da ampliação do rol de legitimados para propositura de ações que tenham como fim a impugnação de Leis ou atos normativos inconstitucionais.

No Brasil, academicamente, se desenvolveu a teoria substancialista, segundo a qual, o controle de constitucionalidade, tanto concentrado como difuso, se justificariam como meio a garantir os direitos das minorias contra interesses das maiorias expressas em leis ou atos normativos violadoras de direitos fundamentais (SAMPAIO, 2013. p. 512).

Porém, atualmente, as decisões proferidas pelo STF, em sede de controle concentrado e abstrato de constitucionalidade, não vêm guardando correspondência com a teoria garantidora mencionada, pois repercutem interesses corporativos de grupos privilegiados, por vezes alheios aos direitos fundamentais.

Apresentado o problema, foi desenvolvida a hipótese segundo a qual, o desenho constitucional dirigido ao controle de constitucionalidade promove a proteção de direitos corporativistas e, tal fato, repercute nas decisões proferidas pelo STF.

Diante do vasto universo, foi promovido recorte temporal e estabelecida restrição ao objeto a ser investigado, com intuito de trazer o posicionamento atual da Corte Constitucional

\footnotetext{
${ }^{313}$ Cumpre observar que a Lei $\mathrm{n}^{\mathrm{o}}$ 9.868, de 10 de novembro de 1999, trouxe a possibilidade excepcional de ser conferida à declaração de inconstitucionalidade efeitos ex nunc.
} 
firmada na principal espécie de ação prevista no controle concentrado, a saber, ADI (Ação Direta de Constitucionalidade).

Como o propósito da investigação era verificar o conteúdo das decisões meritórias do STF, foram afastadas as decisões proferidas pela Corte sem análise de mérito.

Os resultados apresentados na pesquisa correspondem à seleção, sistematização e interpretação dos dados fornecidos pelo site oficial do Supremo Tribunal Federal referentes ao período compreendido entre $1^{\circ}$ de janeiro de 2013 a 10 de novembro de 2015.

Também foram realizadas consultas no campo "pesquisa livre", destinado à apresentação de jurisprudências do STF, por meio das tags: "inconstitucionalidade prox material" e "inconstitucionalidade prox formal", sendo realizada análsie quantitativa e qualitativa das decisões proferidas no lapso do recorte.

Os pesquisadores reconhecem que os critérios utilizados na realização da pesquisa incipiente podem não referendar todas as decisões materiais proferidas pelo STF em sede de ADI no período analisado, contudo, acreditam que o universo investigado será capaz de responder o problema levantado por meio de comparativos razoáveis e com distorções mínimas, se houver.

O presente artigo se desenvolve em duas partes, a primeira consistente na revisão bibliográfica e teórica com a apresentação das matrizes dos controles constitucionais e o desenvolvimento do controle de constitucionalidade no Brasil, sendo ainda abordada a apresentação das teorias procedimentalista e substancialista do controle de constitucionalidade e as espécies de ações que compõem o controle concentrado, segundo o STF; e na segunda parte são apresentados os resultados das pesquisas desenvolvidas conforme recorte e metodologia acima disciplinada possuindo como parâmetro os dados colhidos no site do STF .

\section{MATRIZES DOS CONTROLE CONSTITUTIONAIS}

2.1 Matrizes: norte-americana, francesa e austríaca

A início do controle de constitucionalidade é atribuído ao caso julgado pela Suprema Corte americana, no início do século XIX, conhecido como Marbury vs. Madison ${ }^{314}$, porém,

\footnotetext{
314 Para maior aprofundamento histórico sobre o tema: KLAUTAU FILHO. Paulo. A primeira decisão sobre controle de constitucionalidade: Marbury vs. Madison (1803). Revista Brasileira de Direito Constitucional, v. 2, p. $255-275$. jul./dez. 2003.
} 
CAPPELLETTI (1984, p. 49) afirma que já no antigo Direito ateniense existiam relatos sobre existência de competências legais diversas e métodos específicos para a alteração de normas destinadas a regular a organização do Estado, fato este que estabelecia certa forma de controle exercido para invalidar regras jurídicas vigentes que não observavam pressupostos.

Ainda que presente resquícios históricos anteriores atinentes à possibilidade de controle das normas, o festejado caso Marbury vs. Madison é recebido como a primeira matriz inaugurando o paradigma do controle de constitucionalidade. O julgamento ocorrido em 1803 na Suprema Corte norte-americana deu não só um grande passo para o direito naquele país, mas também para todos sistemas jurídicos, sendo observado em grande parte do mundo.

Para BARROSO (2012, p. 32), o célebre caso inaugurou o controle de constitucionalidade no constitucionalismo moderno, assentado no princípio da supremacia da Constituição e a subordinação de todos ao texto constitucional a qual teria como último interprete o Poder judiciário.

O precedente americano inaugurou o controle jurisdicional de constitucionalidade baseado na ideia de que cada magistrado, individualmente, tem o dever e jurisdição bastante para proteger a supremacia da Constituição e manter a subordinação de todas as demais normas a ao texto constitucional.

Diferente do controle repressivo norte-americano, a matriz francesa introduziu a fiscalização política de constitucionalidade, realizada junto ao Poder Legislativo, ou pelo Chefe do Executivo.

No modelo francês, o controle de constitucionalidade se oferece de forma preventiva, concentrada e possui caráter essencialmente político, cabendo ao Presidente da República, ao Parlamento, ou ao Primeiro Ministro da França apresentar ao Conseil Constitutionnel a norma sobre a qual se questionou a constitucionalidade. Caso o Conselho Constitucional se manifeste pela inconstitucionalidade abstrata do projeto de lei, esta sequer entrará em vigor sendo impedida de ingressar no ordenamento jurídico. (CAPPELLETTI, 1984, p. 28).

Esse caráter político do controle de constitucionalidade francês tem como fundamento uma leitura restrita sobre o respeito ${ }^{315}$ à Teoria da Separação dos Poderes desenvolvida por Montesquieu ${ }^{316}$.

CAPPELLETTI (1984, p.40) ressalta que a criação de um Tribunal de Cassação em

\footnotetext{
315 POLETTI (2001. p. 56) argumenta que se o responsável pela edição das normas é o Poder Legislativo, a tarefa de aferir a constitucionalidade daquelas é do próprio órgão que as criou, e jamais do Judiciário, ao qual compete tão-só a aplicação de tais preceitos normativos.

316 Sobre o tema, conferir: MONTESQUIEU, Charles Louis de. O espírito das leis. São Paulo: Martins. 2005.
} 
1790 junto ao Poder Legislativo tinha o intuito de “[...] evitar que os órgãos judiciários, no exercício de suas funções, invadissem a esfera do poder legislativo, subtraindo-se à estreita $\mathrm{e}$ textual observância das leis.”

Como esclarece MARINONI (2012, p. 758-759) o controle de constitucionalidade francês repercute a desconfiança que sempre existiu sobre o Poder Judiciário, sendo o modelo criado "devoto da ideologia da Revolução francesa, que tentou fazer do juiz a bouche de la $l o i^{317,}$

No período ente guerras do século XX, foi apresentada uma nova matriz de controle de constitucionalidade desenvolvido pelo austríaco Hans Kelsen que objetivava a aferição da constitucionalidade das leis e atos normativos de forma direta, objetiva, abstrata e jurídica a ser exercido por órgão jurisdicional específico.

A proposta apresentada pretendia agregar o que havia de melhor nas duas matrizes anteriores e ao mesmo tempo afastar as suas principais críticas, pois enquanto defendia a jurisdicionalidade da matriz norte-americana e a possibilidade de julgamento abstrato e concentrado da matriz francesa, deixava de lado a difusão e a subjetividade comum da primeira matriz e a politização do modelo francês.

BONAVIDES (2008, p. 309) descreve o sistema austríaco, ou europeu, da seguinte maneira:

(...) a idéia de constituir um órgão jurisdicional que enfeixasse toda a competência decisória em matéria de constitucionalidade - o sistema de "jurisdição concentrada" - partiu de Kelsen e se positivou na Constituição austríaca de $1^{\circ}$ de outubro de 1920, de que foi ele abalizado inspirador. Disso resultou o chamado sistema austríaco de controle da constitucionalidade, exercitado por "via principal" e concentrado numa Corte especial, em contraste com o sistema americano clássico, de controle difuso, por via de exceção, e que só se faz absoluto ou definitivo quando a decisão judicial se contém num arresto da Suprema Corte.

2.2 O Brasil e as matrizes de controle de constitucionalidade

A Constituição Imperial, promulgada em 25 de março de 1824, sofreu forte influência da doutrina filosófica europeia - notadamente da revolução francesa -, e, assim sendo, o foco das questões estatais estava no Parlamento, sendo que cabia ao Poder Legislativo criar as leis e interpretá-las. Em função disso, o controle de constitucionalidade que existia naquela época era essencialmente político, e o Poder Judiciário ficava alheio a tais questões (PAGANELLA, 2007, p. 13-14).

\footnotetext{
317 Tradução livre: Boca da lei.
} 
Não obstante fosse por influência dos ideais advindos da Revolução Francesa, não foi esse o único motivo para o afastamento das questões constitucionais do Poder Judiciário. Além do fato de que naquela época a separação dos poderes tinha caráter absoluto, e, por esse motivo, cabia ao Legislativo à edição e interpretação das normas em geral, havia na Constituição de 1824 a previsão de um quarto Poder, chamado Moderador. Segundo a dicção do artigo 98 do texto constitucional de 1824:

O Poder Moderador é a chave de toda a organização Politica, e é delegado privativamente ao Imperador, como Chefe Supremo da Nação, e seu Primeiro Representante, para que incessantemente vele sobre a manutenção da Independencia, equilibrio, e harmonia dos mais Poderes Politicos.

De fato, a influência do Poder Moderador era tal, que o Imperador tinha a possibilidade de intervir nos demais Poderes, “[...] ficando quimérica a possibilidade de que o verdadeiro constituinte de 1824 fosse atribuir a órgão ou Poder outro a competência para controlar a constitucionalidade das leis" (PALU, 2001, p. 121).

Assim, a Carta Imperial de 1824 inviabilizou o controle jurisdicional de constitucionalidade, algo que somente chegou ao Brasil com a instauração da República e sua Constituição de 24 de fevereiro de 1891.

Com efeito, o regime republicano repartiu as funções estatais em três, Judiciário, Legislativo e Executivo, abolindo o poder moderador.

Além disso, outra alteração importante é a ruptura com os ideais franceses que fundamentaram a Carta do Império, inserindo-se no Brasil uma ordem constitucional fortemente influenciada pelo direito estadunidense (BARBI, 2011, p. 91). Diga-se de passagem, os EUA haviam afirmado os preceitos da supremacia da Constituição sobre as demais normas e sobre os Poderes do Estado quase 90 (noventa) anos antes de promulgada a primeira Constituição republicana do Brasil.

No tocante ao controle de constitucionalidade "fica claro uma tendência de fazer uma adaptação do modelo norte-americano" (TREVISAN, 2009. p. 9) no Brasil, que passou a adotar o sistema jurisdicional, incidental e difuso de Controle de constitucionalidade.

BARBOSA (1910. p. 103), mentor da primeira Constituição republicana, atento a teoria da separação dos poderes, advertia que o Poder Judiciário não possui o poder de anular qualquer legislação, possuindo o poder de declarar a sua nulidade das leis inconstitucionais.

Com relação ao controle de constitucionalidade, Mendes (2009, p. 1.085) destaca que a Constituição de 1891 reconheceu a competência do STF como tribunal recursal de última instância quando questionado a validade ou a aplicação de tratados e leis federais e a decisão 
do Tribunal, de leis ou de atos dos governos locais em face da Constituição ou das leis federais, e a decisão do Tribunal considerasse válidos esses atos ou leis impugnadas.

Mesmo estando expressa ${ }^{318}$ na Constituição de 1891, os magistrados do país demoraram a se acostumar com tal poder. Problemas na dicção dos dispositivos constitucionais, e a falta de prática dos magistrados brasileiros foram empecilhos para elevar a efetividade das inovações trazidas pela Constituição de 1891 (DANTAS, 2001, p. 85-86).

Apenas com a edição da Lei $\mathrm{n}^{\circ}$ 221, de 20 de novembro de 1894, tornou-se mais clara a função protetiva que o Poder Judiciário exercia sobre a Constituição, sendo prevista a possibilidade doa juízes e tribunais apreciarem a validade das leis e regulamentos, podendo não aplica-las, ao caso concreto quando manifestamente incompatível com a Constituição. Resolveu, então, lacuna contida no artigo 60 da Constituição de 1891, deixando claro que a atribuição era não só dos tribunais, mas também dos juízes singulares.

Entretanto, veja-se que apesar das mudanças terem sido positivas, que concederam independência ao judiciário, este se manteve distante das questões que considerava política (DALLARI, 2010, p. 336-337).

Introduzido em terras brasileiras com a Constituição de 1891, o modelo jurisdicional de controle de constitucionalidade passou a ganhar maior notoriedade e eficácia com a Constituição, de 16 de julho de 1934. Este diploma constitucional, o terceiro do nosso país, manteve o controle difuso de normas, e previu, pela primeira vez, uma forma concentrada, concreta e muito restrita de fiscalização, direcionada a declaração de constitucionalidade de lei interventiva federal decretada por violação a princípios constitucionais sensíveis ${ }^{319}$ (BARROSO, 2012, p. 85-86).

A Constituição de 1934 também trouxe inovações ao controle constitucional difuso, primeiramente atribuindo ao Senado poderes para estender os efeitos da declaração de inconstitucionalidade efetuada pelo Poder Judiciário a todos, concedendo eficácia geral a decisão proferida em âmbito particular (MENDES, 2009. p. 1086-1087).

A segunda inovação se deu com a instituição da cláusula de reserva de plenário em que somente por maioria absoluta de votos da totalidade dos seus magistrados os Tribunais poderiam declarar a inconstitucionalidade de lei ou ato do Poder Público.

Note-se que em que pese tenha sido a que menos tempo ficou em vigor na história do

\footnotetext{
${ }^{318}$ Art 60 - Compete aos Juízes ou Tribunais Federais, processar e julgar:

a) as causas em que alguma das partes fundar a ação, ou a defesa, em disposição da Constituição federal;

319 PONTE DE MIRANDA (1970. p. 286) argumenta que seriam princípios sensíveis todos aqueles que indubitavelmente enumerados para a organização dos estados-membros, que quando violados, autorizam a intervenção federal, para assegurar a prevalência da ordem constitucional.
} 
Brasil, a Constituição de 1934 trouxe grandes avanços no campo do controle de constitucionalidade, revolucionando o constitucionalismo brasileiro, com inserções de inovações que subsistem até os dias atuais.

Em 1937 o Brasil sofreu uma revolução política que modificou a ordem constitucional vigente, e instaurou outra, centralizadora e autoritária baseada na Constituição Polonesa de 1935 (PAGANELLA, 2007, p. 29).

A Constituição, de 10 de novembro de 1937, deixou de lado a competência do Senado para suspender atos declarados inconstitucionais pelo Poder Judiciário, manteve a cláusula de reserva de plenário (artigo 96) e proibiu o Poder Judiciário de conhecer de questões exclusivamente políticas (artigo 94), repetindo os demais preceitos contidos na Carta de 1934.

Contudo, descreve MENDES (2009. p. 1088) que a declaração de inconstitucionalidade da uma lei declarada pelo Presidente da República como "necessária ao bem-estar do povo, à promoção ou defesa de interesse nacional" poderia ser submetida pelo chefe do executivo ao Parlamento, que, por sua vez, poderia confirma-la, mediante aprovação por quórum qualificado tornando insubsistente a decisão do Tribunal ${ }^{320}$.

Com a promulgação da Constituição, de 18 de setembro de 1946, foi restaurada a dinâmica da Constituição de 1934, salvo a prerrogativa ampla que o Senado possuía de suspender a eficácia de norma e atos declarados inconstitucionais pelo Poder Judiciário, pois, agora esta competência somente poderia ser exercida quando o Supremo Tribunal Federal declarasse a inconstitucionalidade de leis ou decretos (VELLOSO, 2011. p. 80), ou seja, o a lei reconhecida inconstitucional por juízes singulares ou Tribunais inferiores, assim como atos proferidos pelo chefe do poder executivo não poderiam ser suspenso (CARVALHO, 2010, p. 435-436).

A Constituição de 1946 foi modificada pela Emenda Constitucional nº 16, de 06 de dezembro de 1965, que introduziu o controle constitucional concentrado e abstrato de lei ou ato de natureza normativa, sem excluir, entretanto, o controle concreto, incidental e difuso previsto constitucionalmente desde a primeira república.

O controle de constitucionalidade com raízes na matriz austríaca possui apenas o Procurador Geral da República como legitimado a propor ação direta de inconstitucionalidade dirigida exclusivamente ao Supremo Tribunal Federal, a quem possuía status de Corte Constitucional, revisora e ordinária.

A EC $n^{\circ} .16 / 65$ inseriu a possibilidade de todas as leis estaduais e federais do

320 A Constituição outorgada em 1937 foi e ainda é alvo de severas críticas de inúmeros autores como, vg: BULOS (2011, p. 197), BONAVIDES (2008, p. 328), DALLARI (2010, p. 337) e MENDES (2009, p. 1088). 
ordenamento jurídico terem questionadas, mediante ação direta de inconstitucionalidade, sua eficácia no ordenamento jurídico nacional a serem julgadas pelo STF (BONAVIDES, 2008. p. $330)$.

A referida Emenda também abriu a possibilidade do Tribunal de Justiça Estadual controlar a constitucionalidade de Lei ou ato municipal que conflitar com a Constituição do Estado.

A Constituição, de 05 de outubro de 1988, manteve as principais diretrizes do controle de constitucionalidade fixadas na emenda constitucional apresentada, conservando o modelo misto de controle de constitucionalidade, todavia, como observa COSTA (2013. p. 3-4) houve uma ampliação do rol de legitimados a propor ações diretas e concedida maior autonomia ao Procurador Geral da República.

Porém, na década seguinte à promulgação da Constituição de 1988, foram criadas outras ações, alternativas a ação direta de inconstitucionalidade e ação declaratória de inconstitucionalidade por omissão, também destinadas ao controle concentrado e abstrato de constitucionalidade como: ação direta de constitucionalidade e arguição de descumprimento de preceito fundamental ${ }^{321}$; além da possibilidade de modulação dos efeitos da decisão ${ }^{322}$.

O controle difuso também sofreu alterações importantes como a possibilidade de edição de súmula vinculante ${ }^{323}$ a todos os demais órgãos do Poder Judiciário e à Administração Pública direta e indireta pelo STF, e a introdução do princípio da seletividade dos recursos, introduzido pela necessidade de demonstração de repercussão geral ${ }^{11}$ das questões suscitadas no controle concreto, o que reduziu sobremaneira o acesso ao Poder Judiciário pelo cidadão comum (COSTA, 2013. p. 4).

O controle de constitucionalidade de matriz norte-americana presente em seis das sete ${ }^{324}$ Constituições brasileiras vem perdendo espaço junto ao STF no sistema constitucional atualmente desenhado, em virtude da seletividade, discricionária, atribuída ao Tribunal para escolher as ações que deseja julgar.

Diante das dificuldades impostas aos cidadãos, as defesas dos direitos fundamentais que, porventura, estiverem sendo violados ou ameaçados por leis ou atos normativos estão sujeitas à propositura de ações diretas a serem promovida conforme interesse dos legitimados arrolados no texto constitucional.

\footnotetext{
${ }^{321} \mathrm{Cf}: \mathrm{EC} \mathrm{n}^{\circ}$ 03, de 17 de março de 1993.

${ }^{322}$ Cf: Lei 9868 , de 10 de novembro de 1999.

${ }^{323}$ Cf: EC no 45 , de 30 de dezembro de 2004.

${ }^{324} \mathrm{O}$ controle de constitucionalidade difuso esteve presente nas constituições de 1891, 1934, 1937, 1946,1967 e 1988, somente ausente na Constituição de 1824.
} 
COSTA (2013. p. 5-6) adverte que o controle de constitucionalidade de matriz austríaca foi introduzido no Brasil no período do governo militar (1965) e serviu aos interesses desses e não aos desejos da população, restando ainda hoje seleto o grupo daqueles que possuem a prerrogativa para acionar validamente o STF por meio do controle concentrado de constitucionalidade, o que invariavelmente, repercute na concentração de poder e na defesa de interesses corporativistas.

\section{TEORIA PROCEDIMENTALISTA E SUBSTANCIALISTA DO CONTROLE DE CONSTITUCIONALIDADE}

SAMPAIO (2013. p. 510) observa que "o crescimento dos poderes legislativos, a evolução do constitucionalismo revelou um desvio de rumos", pois, os representantes do povo deixaram de defender os interesses daqueles que o elegeram para defender os interesses próprios ou de grupos de apoio.

Diante desse fato, as Cortes constitucionais passaram a ser vistas como representantes a defender os interesses do povo corrigindo os desvios praticados pelo legislador em seus trabalhos ordinários que contrariassem as decisões constitucionais tomadas quando da mobilização em favor das mudanças políticas.

Envolto nesse cenário, duas teorias democráticas foram desenvolvidas: a procedimentalista e a substancialista, possuindo ambos, o mesmo objetivo, a defesa das minorias contra a maioria.

Para ELY (2010, p. 156), cabe ao Poder Judiciário por meio do controle de constitucionalidade afastar normas ou ato normativos que venham a obstruir os processos democráticos estabelecidos constitucionalmente, como forma de garantir o pluralismo social e político.

Observa-se que ao Pode Judiciário não é permitido exercer juízo de valor sobre as escolhas consagradas constitucionalmente, isto porque, "os valores substantivos de uma sociedade devem ser escolhidos por meio de uma deliberação democrática, ou seja, pelos poderes representativos do povo, quais sejam o Poder Executivo e o Poder Legislativo". (KOZICKI, 2008. p. 6761)

Zagrebeslky apud SAMPAIO (2013. p. 512) explicita que para a teoria procedimentalista a primeira preocupação da justiça constitucional seria a possibilidade de assegurar condições de igualdade dirigida ao procedimento, somente em um segundo momento 
caberia a defesa das condições de existência da própria Constituição.

Contudo, fundado no movimento neoconstitucionalista ${ }^{325}$ apenas o respeito às normas constitucionais procedimentais não são suficientes para realizar a supremacia e efetividade constitucional, com este fundamento se desenvolveu a teoria substancialista do controle de constitucionalidade.

A teoria substancialista busca proteger as minorias não apenas garantindo a manutenção das "regras do jogo", como a teoria procedimentalista, até porque tal, posicionamento conservador é contrário ao regime democrático que exige a igualdade material como meio a alcançar a justiça, mas também atendendo as necessidades básicas já consagradas expressamente no texto constitucional ou mesmo aquelas que ainda não foram reconhecidas, mas que possam ser identificadas em enunciados abertos de princípios constitucionais (SAMPAIO, 2013. p. 512-513).

Neste mesmo sentido DWORKIN (2007, p. 379):

(...) a isso que chamarei de ponto de vista da intenção do locutor pois supõe que a legislação é uma ocasião ou um exemplo de comunicação, e que os juízes se voltam para a história legislativa quando uma lei não é clara, para descobrir qual era o espírito que os legisladores tentaram comunicar através de seus votos.

A crítica procedimentalista à teoria substancialista reside da possibilidade de usurpação da função típica legiferante do Poder Legislativo pelo Judiciário, todavia, MENDES (2008. p. 134) arrimado na teoria de Ronald Dworkin aduz que a decisão legislativa está fundada em argumentos jurídicos principiológicos e políticos voltados a algum objeto coletivo ou bem estar geral, enquanto a decisão jurídica observam apenas princípios jurídicos.

Duas conclusões decorrem do raciocínio descrito acima, o primeiro é que, o princípio prevalece sobre decisões majoritárias, pois tem por fundamento um direito moral e, o segundo, que o Judiciário não poderá rever o mérito da decisão política a qual cabe ao representante democraticamente escolhido para tanto.

\section{AÇÕES NO CONTROLE CONCENTRADO}

As ações judiciais propostas por via de controle concentrado e abstrato possuem efeitos

\footnotetext{
325 O neoconstitucionalismo é aqui compreendido como o movimento surgido em meados do século XX, após Segunda Guerra Mundial que reconheceu a força normativa de princípios e valores constitucionais, determinando a expansão da jurisdição constitucional e o desenvolvimento de uma nova hermenêutica centralizada no texto constitucional. (BARROSO, 2005. p. 3 e 6)
} 
jurídicos que transcendem os desejos e interesses de seus autores, pois possuem repercussão erga omnes e têm como finalidade a defesa da ordem jurídica, não se destinando à defesa de direitos subjetivos disponíveis, ou seja, a decisão proferida em sede de controle concentrado ecoa em toda a sociedade.

Em virtude desse importante e longo alcance será intensificado o recorte da pesquisa, sendo apresentado, neste momento, as principais características das ações que compõem o controle concentrado e as especificidade de cada uma.

As ações do controle concentrado de constitucionalidade, também chamado de controle abstrato - posto que seu objeto é o ato normativo abstratamente considerado e não o ato diante de uma situação concreta - são regidas pela Constituição Federal, notadamente em seus art. 102 e art. 103, além das leis $\mathrm{n}^{\text {os }} 9.868$, de 10 de novembro de 1999 , e 9.882 , de 03 de dezembro de 1999.

Integram o controle concentrado de constitucionalidade ${ }^{326}$ : a ação direta de inconstitucionalidade (ADI); ação declaratória de constitucionalidade (ADC); ação direta de inconstitucionalidade por omissão (ADO) e arguição de descumprimento de preceito fundamental (ADPF).

Segundo entendimento do Supremo Tribunal Federal, o controle concentrado de constitucionalidade possui caráter indisponível ${ }^{327}$ e natureza objetiva ${ }^{328}$, pois, nos termos do artigo $5^{\circ}$ da Lei $n^{\circ}$ 9868/99 329 , "proposta a ação direta, não se admitirá desistência" uma que a

\footnotetext{
${ }^{326}$ Conforme disposto por LENZA (2015. p. 459), o controle da ordem constitucional realizado pelo STF sobre a representação interventiva (art. 34 da CRFB) é realizado sobre caso concreto que lhe é submetido, razão pela qual não se amolda às balizas do recorte desta pesquisa que trata das ações de controle concentrado e abstrato julgados pelo STF.

${ }^{327}$ Sobre o princípio da indisponibilidade, o STF tem entendido, conforme decisão proferida na ADI 387-MC, rel. min. Celso de Mello, que "o princípio da indisponibilidade, que rege o processo de controle concentrado de constitucionalidade, impede a desistência da ação direta já ajuizada. O art. $169, \S 1^{\circ}$, do RISTF-80, que veda ao PGR essa desistência, aplica-se, extensivamente, a todas as autoridades e órgãos legitimados pela Constituição de 1988 para a instauração do controle concentrado de constitucionalidade (art. 103)."

${ }^{328}$ Sobre o caráter objetivo da ADIn, o STF no julgamento da ADI 1.254 - AgR, assim se manifestou: "Ação direta de inconstitucionalidade. Processo de caráter objetivo. Inclusão de entidade privada no polo passivo da relação processual. Inadmissibilidade. [...] Não se discutem situações individuais no âmbito do controle abstrato de normas, precisamente em face do caráter objetivo de que se reveste o processo de fiscalização concentrada de constitucionalidade. $O$ círculo de sujeitos processuais legitimados a intervir na ação direta de inconstitucionalidade revela-se extremamente limitado, pois nela só podem atuar aqueles agentes ou instituições referidos no art. 103 da Constituição, além dos órgãos de que emanaram os atos normativos questionados. A tutela jurisdicional de situações individuais - uma vez suscitada controvérsia de índole constitucional - há de ser obtida na via do controle difuso de constitucionalidade, que, supondo a existência de um caso concreto, revela-se acessível a qualquer pessoa que disponha de legítimo interesse (CPC, art. $\left.3^{\circ}\right)$.”

329 Há que se destacar que na Lei que regulamenta a ADPF, Lei $\mathrm{n}^{\circ}$ 9882/99, não existe dispositivo infraconstitucional com teor semelhante àquele declinado do art. $5^{\circ}$ da Lei $n^{\circ} 9868 / 99$, referente à inadmissão de desistência da propositura da ação, entretanto, fundamentando nas mesmas razões acima esposadas compreendemos que também deve ser negada a possibilidade de desistência. Contrário ao nosso entendimento, vide: ADPF 108, Relatoria: Min. Cármen Lúcia.
} 
ação possui como finalidade a defesa da ordem jurídica, não se destinando à defesa de direitos subjetivos disponíveis.

Outro ponto de destaque nesta introdução às ações do controle concentrado diz respeito à aplicabilidade do artigo 52, inciso $\mathrm{X}$ da $\mathrm{CRFB} / 88$, que atribui competência ao Senado Federal para suspender a execução, no todo ou em parte, de lei declarada inconstitucional por decisão definitiva do Supremo Tribunal Federal.

Neste caso, o STF, no RE 199.293-0/SP com relatoria do Min. Marco Aurélio, consolidou o entendimento segundo o qual a comunicação para o Senado Federal suspender a lei declarada inconstitucional, no todo ou em parte, deve ocorrer nos casos de declaração de inconstitucionalidade proferida no âmbito do controle difuso, ou seja, no caso concreto, afastando tal exigência nas hipóteses do controle concentrado/abstrato, dada a natureza própria das vias difusa/concentrada.

Feitas essas primeiras considerações, passamos a analisar brevemente as quatro ${ }^{330}$ ações possíveis no controle concentrado de constitucionalidade.

\subsection{Ação direta de inconstitucionalidade - ADI}

A ADI consagrada na Constituição vigente possui origem na ação de representação interventiva $^{331}$ proclamada na Constituição de 1934 a qual competia exclusivamente ao Procurador-Geral da República a sua propositura, conforme descrito no capítulo segundo deste estudo.

Naquela oportunidade, a ação interventiva se valia como um instrumento para a solução de conflitos entre o estado-membro e a União, modelo bem diverso do atualmente desenvolvido pela ADI.

A ADI foi encartada no artigo 102 CRFB/88, em artigo que trata sobre as competências do STF, sendo objeto da ação pretensão consubstanciada na retirada de lei ou atos normativos editados após a égide da Constituição de 1988 e ainda assim contrários a ela, buscando a manutenção e o restabelecimento da harmonia no sistema jurídico constitucional evitando que leis ou atos normativos contrários aos seus preceitos sejam aplicados, em reverencia à teoria neoconstitucionalista.

\footnotetext{
${ }^{330}$ FALCÃO (2001. p. 19) também considera que tanto o Mandado de Injunção (MI) como a Proposta de Súmula Vinculante (PSV) compõe o rol de ações do controle concentrado o que amplia a classificação atualmente utilizada pelo STF.

331 Para uma melhor compreensão do tema recomenda-se a leitura: MENDES, Gilmar. A representação interventiva. Direito público, v. 3, n. 9, p. 3-32, jul./set. 2005.
} 
A possibilidade de extirpar do ordenamento jurídico leis ou atos normativos contrários à Constituição Federal também se coaduna com as teorias procedimentalista e/ou substancialistas, cabendo ao STF tanto o julgamento das questões procedimentais como análise substancial da Lei colocada em xeque frente à Constituição.

As espécies normativas sujeitas ao controle da ADI estão enumeradas no art. 59 da $\mathrm{CRFB} / 88^{332}$, porém, como se denota da alínea a do inciso I do art. 102, também estão sujeitos ao controle de constitucionalidade "atos normativos" como, vg, resoluções administrativas de tribunais.

Diferente a posição autoritária da EC n 16/65, a Constituição de 1988 inovou ao ampliar o rol dos legitimados a propor ADI, antes reservada apenas ao Procurador-Geral da República (MORAES, 2008. p. 741), atualmente compreende nove legitimados sendo eles: o Presidente da República; a Mesa do Senado Federal; a Mesa da Câmara dos Deputados; a Mesa de Assembleia Legislativa ou da Câmara Legislativa do Distrito Federal ${ }^{333}$; o Governador de Estado ou do Distrito Federal; o Procurador Geral da República; o Conselho Federal da Ordem dos Advogados do Brasil; o Partido Político com representação no Congresso Nacional e a Confederação sindical ou entidade de classe de âmbito nacional.

Para alguns legitimados, o STF passou a exigir demonstração de "pertinência temática", inicialmente apenas para entidades de classe ${ }^{334}$, posteriormente também para Confederações sindicais $^{335}$, Governadores do Estado ou do Distrito Federal ${ }^{336}$ e Mesa da Assembleia Legislativa ou da Câmara Legislativa do Distrito Federal ${ }^{337}$.

Com isso os autores passam a classificar os legitimados em: legitimados universais e legitimados especiais ${ }^{338}$, sendo estes últimos exatamente aqueles que deverão cumprir a exigência da pertinência temática para o manejo da ADI.

Para CRUZ (2004, p. 379) a limitação, jurisprudencial, promovida pelo STF seria

\footnotetext{
332 Art. 59. O processo legislativo compreende a elaboração de:

I - emendas à Constituição;

II - leis complementares;

III - leis ordinárias;

IV - leis delegadas;

$\mathrm{V}$ - medidas provisórias;

VI - decretos legislativos;

VII - resoluções.

${ }^{333}$ Inserido pela $\mathrm{EC} \mathrm{n}^{\circ}$ 45, de 30 de dezembro de 2004.

${ }^{334}$ Cf: ADI-MC 138, ADI-396, ADI 893.

${ }^{335} \mathrm{Cf}:$ ADI-MC 1.151, ADI 1.114.

${ }^{336} \mathrm{Cf}$ : ADI 902.

${ }^{337} \mathrm{Cf}$ : ADI 1.307-6.

338 Cf: BINEMBOJM, Gustavo. A nova jurisdição constitucional: legitimidade democrática e instrumentos de realização. Rio de Janeiro: Renovar, 2004; e MORAES, Alexandre de. Direito Constitucional. São Paulo: Atlas. 2008.
} 
indevida uma vez que a Constituição de 1988 procurou, com a ampliação do rol dos legitimados, democratizar o controle abstrato de normas, razão pela qual deveria pairar presunção de interesse genérico sobre todos os legitimados, fato este que preservaria a supremacia constitucional ${ }^{339}$.

Contudo, cumpre destacar que a ampliação do rol de legitimados não possuía como finalidade a democratização do controle abstrato de normas, primeiramente porque se este fosse o objetivo, o acesso não se daria em numerus clausus (art. 103), e em segundo lugar os debates travados na Assembleia Constituinte ${ }^{340}$ demonstram o sentido corporativista previsível do sistema (COSTA, 2013. p. 27-28).

Admitindo-se o caráter corporativista de acesso ao controle concentrado, se tem por acertada a interpretação sistemática constitucional promovida pelo STF que limita sensivelmente a possibilidade atuação que ultrapassasse a defesa dos próprios interesses, por meio da "pertinência temática".

Sobre o entendimento do supracitado autor, alguns pontos merecem ser destacados, o primeiro refere-se à motivação que determinou a ampliação do rol de legitimados e o segundo relaciona-se ao elo apontando entre a supremacia constitucional e a presunção de interesse genérico de todos os legitimados.

Partindo da premissa de que uma lei declarada inconstitucional é nula, ou seja, não é crível que uma lei inconstitucional seja válida e aplicada no sistema normativo, exatamente por não preencher os moldes de validade constitucional, é certo que a norma jurídica não pode gerar direitos e obrigações.

\footnotetext{
339 " $\mathrm{O}$ art. 103 da Carta atual procurou democratizar o controle abstrato de normas. Viu-se que no regime anterior a limitação do direito de propositura ao Procurador-Geral da República, cargo de livre nomeação no período do regime militar, servia exclusivamente aos interesses da ditadura. Logo, certamente, todo o rol de instituições elencadas naquele dispositivo deveria ter presunção de interesse genérico na preservação da supremacia constitucional. Todavia, não procedeu assim o Supremo. Ao eleger o vínculo de pertinência temática como condição objetiva do processo à qualificação da legitimidade, o Supremo limitou, indevidamente, sua acessibilidade especialmente aos órgãos da sociedade civil."

340 O discurso do Deputado Antônio Morimoto do PMDB/RO junto à comissão de sistematização, proferido em 31 de agosto de 1987, deixa clara a feição corporativista conferida aos legitimados para propor ação direta ao STF, senão vejamos: No anteprojeto, tal como foi inicialmente divulgado pela Comissão de Sistematização, há, em parte, sensível melhora, pela abertura que dá, para que determinadas autoridades e entidades representativas da sociedade possam propor a ação direta de inconstitucionalidade. Neste aspecto, a emenda por que propugnamos nós, o povo de Rondônia - abre mais o leque, uma vez que incluímos à mesa das Assembléias Legislativas, as Federações e não apenas as Confederações Sindicais, e os Conselhos Estaduais da OAB e não apenas o Conselho Federal, isso com a finalidade de permitir uma ação mais pronta da Sociedade, ao reagir contra a ilegalidade. Também retiramos do texto original a restrição, que nos pareceu iníqüa, limitando a autoria da ação direta de inconstitucionalidade aos partidos políticos com assento no Congresso. E não esqueçamos de que o PMDB é o meu Partido e o Partido da simpatia da maioria do povo rondoniense. Mas não é possível discriminar entre partidos políticos legalmente constituídos, desde que com existência legal; deve um partido político estar apto a exercer a representação de seus adeptos, que são uma parcela do povo. (p. 415-416) (grifo nosso) Disponível em: http://www.senado.gov.br/publicacoes/anais/constituinte/sistema.pdf Acessado em 21 de jan de 2016.
} 
A respeito disso poderá o STF passar por momentos em que a norma declarada inconstitucional produziu efeitos e a segurança jurídica ser chamada ao debate, a fim de solucionar casos em que a lei inconstitucional produziu efeitos e serviu de base jurídica para a prática de atos.

Para solucionar eventuais ocorrências, como a acima tratada, é que o artigo 27 da lei 9.868, de 10 de novembro de 1999, possibilita a chamada "modulação dos efeitos", que mantém a regra dos efeitos ex tunc, isto é, da retroatividade dos efeitos da decisão até o momento que nasce a norma inconstitucional; porém, excepcionalmente, poderá o STF deliberar sobre outro momento em que os efeitos da inconstitucionalidade poderão ser aplicados, privilegiando, assim, a segurança jurídica.

Trata-se de um modelo bifásico de análise, como se pode perceber. Nesse sentido, no primeiro momento o STF decide pela constitucionalidade ou não da norma, objeto da ação e, em segunda análise, delibera pela modulação dos efeitos da decisão.

\subsection{Ação direta de inconstitucionalidade por omissão - ADO}

A ação de inconstitucionalidade por omissão encontra-se prevista no $2^{\circ}$ do artigo 103 da CRFB/88 e tem por objetivo cientificar a necessidade da criação da norma para assegurar o direito pleiteado, resultando em uma comunicação do STF ao poder inadimplente para que supra essa omissão normativa.

A lei 9868/99 descreve para essa ação os mesmos legitimados para a ADI e ADC e tem por objeto, portanto, a omissão total ou parcial quanto ao cumprimento de dever constitucional de legislar ou quanto à adoção de providência de índole administrativa.

Sobre a importância desta ação, BAROUCH (2015. p. 95) de forma eloquente argumenta que a Constituição de 1988 descreveu inúmeros direitos e garantias individuais e coletivos e a efetivação plena destes, muitas vezes, necessita de uma atitude pró ativa do poder legislativo, caso contrários resta passível a possibilidade de reconhecimento de sua inadimplência.

A Constituição de 1988 estabeleceu em seu art. 103, §2 o efeito da sentença que reconhece a mora legislativa por meio da $\mathrm{ADO}$, efeito este que se resume a dar ciência ao Legislativo de sua inadimplência.

No mesmo dispositivo citado, ao tratar da mora administrativa, a Constituição apresenta 
efeitos concretos e mais contundentes, designando prazo de trinta dias ${ }^{341}$ para suprir a omissão, sob pena de responsabilidade.

LENZA (2015. p. 453-457) argumenta acerca dos efeitos da ADO e destaca a decisão proferida na $\mathrm{ADO}^{\mathrm{o}} 3682^{342}$, em 09 de maio de 2007, sob a relatoria do Min. Gilmar Mendes, alterou, ainda que timidamente, a jurisprudência do STF que passou a admitir a fixação de prazo razoável para que o Parlamento supra a mora legislativa ${ }^{343}$.

\subsection{Ação Declaratória de Constitucionalidade - ADC}

\section{A ADC foi originariamente prevista no $\S 4^{\circ}$ do artigo 103 da CRFB/88, fruto da Emenda}

Constitucional n. 3 de 1993, e serve a declarar a constitucionalidade de lei federal quando há, notadamente, divergência pretoriana relevante sobre a aplicação do dispositivo que motiva a ação, conforme inteligência do inciso III do artigo 14 da Lei $9868 / 99^{344}$ ou forte insegurança

${ }^{341} \mathrm{O}$ art. 12-h, $\S 1^{\circ}$ da Lei 9868/99, deferentemente do texto constitucional, estabelece que: "Em caso de omissão imputável a órgão administrativo, as providências deverão ser adotadas no prazo de 30 (trinta) dias, ou em prazo razoável a ser estipulado excepcionalmente pelo Tribunal, tendo em vista as circunstâncias específicas do caso e o interesse público envolvido".

342 AÇÃO DIRETA DE INCONSTITUCIONALIDADE POR OMISSÃO. inatividade do legislador quanto ao dever de elaborar a Lei Complementar a que se refere o § 4o do art. 18 da Constituição Federal, na redação dada pela Emenda Constitucional no 15/1996. ação julgada procedente.

1. A Emenda Constitucional $n^{\circ} 15$, que alterou a redação do $\S 4^{\circ}$ do art. 18 da Constituição, foi publicada no dia 13 de setembro de 1996. Passados mais de 10 (dez) anos, não foi editada a lei complementar federal definidora do período dentro do qual poderão tramitar os procedimentos tendentes à criação, incorporação, desmembramento e fusão de municípios. Existência de notório lapso temporal a demonstrar a inatividade do legislador em relação ao cumprimento de inequívoco dever constitucional de legislar, decorrente do comando do art. 18, § 4o, da Constituição.

2. Apesar de existirem no Congresso Nacional diversos projetos de lei apresentados visando à regulamentação do art. $18, \S 4^{\circ}$, da Constituição, é possível constatar a omissão inconstitucional quanto à efetiva deliberação e aprovação da lei complementar em referência. As peculiaridades da atividade parlamentar que afetam, inexoravelmente, o processo legislativo, não justificam uma conduta manifestamente negligente ou desidiosa das Casas Legislativas, conduta esta que pode pôr em risco a própria ordem constitucional. A inertia deliberandi das Casas Legislativas pode ser objeto da ação direta de inconstitucionalidade por omissão.

3. A omissão legislativa em relação à regulamentação do art. $18, \S 4^{\circ}$, da Constituição, acabou dando ensejo à conformação e à consolidação de estados de inconstitucionalidade que não podem ser ignorados pelo legislador na elaboração da lei complementar federal.

4. Ação julgada procedente para declarar o estado de mora em que se encontra o Congresso Nacional, a fim de que, em prazo razoável de 18 (dezoito) meses, adote ele todas as providências legislativas necessárias ao cumprimento do dever constitucional imposto pelo art. $18, \S 4^{\circ}$, da Constituição, devendo ser contempladas as situações imperfeitas decorrentes do estado de inconstitucionalidade gerado pela omissão. Não se trata de impor um prazo para a atuação legislativa do Congresso Nacional, mas apenas da fixação de um parâmetro temporal razoável, tendo em vista o prazo de 24 meses determinado pelo Tribunal nas ADI n ${ }^{\circ}$ s 2.240, 3.316, 3.489 e 3.689 para que as leis estaduais que criam municípios ou alteram seus limites territoriais continuem vigendo, até que a lei complementar federal seja promulgada contemplando as realidades desses municípios.

Liminar proferida na medida cautelar na ADO 24 (DJe. 01 de jul 2013) conferiu prazo de 120 dias para que o Congresso Nacional elabore a lei de defesa do usuário de serviços públicos.

${ }^{343}$ Liminar proferida na medida cautelar na ADO 24 (DJe. 01 de jul 2013) conferiu prazo de 120 dias para que o Congresso Nacional elabore a lei de defesa do usuário de serviços públicos.

344 Art. 14. A petição inicial indicará:

I - o dispositivo da lei ou do ato normativo questionado e os fundamentos jurídicos do pedido; 
jurídica quanto à sua aplicabilidade.

A ADC provocou intenso debate no $\mathrm{STF}^{345}$, pois, a prima face, contrariava posições firmes na Corte, segunda a qual, toda lei é presumidamente constitucional não necessitando de decisão judicial que lhe confira tal assertiva; segundo, que a ADI comporta natureza jurídica dúplice, ou seja, uma vez improcedente a ação direta de inconstitucionalidade, a lei será constitucional; por outro lado, declarada inconstitucional, deverá ser retirada do sistema jurídico, não havendo assim, espaço destinado à ADC.

Muito embora os debates e divergências, a ação declaratória é amplamente admitida pela jurisprudência do STF, sendo ainda compatível com as posições anotadas acima, pois, visa trazer segurança jurídica em momento específico de insegurança provocada por decisões judiciais conflitantes em sede de controle de constitucionalidade difuso.

Em relação ao rol de seus legitimados, a Emenda Constitucional n ${ }^{\circ}$ 03, de 17 de março de 1993, que tratou da ADC, arrolou, em numerus clausus, o Presidente da República, Mesa do Senado e da Câmara dos Deputados e o Procurador Geral da República.

Posteriormente, a $\mathrm{EC} \mathrm{n}^{\circ} 03$ foi revogada pela $\mathrm{EC} \mathrm{n}^{\circ} 45$, com isso, o rol de legitimados foi ampliado se tornando os mesmos definidos à ADI.

A decisão proferida na ADC são os mesmos da ADI, a exceção da possibilidade de modulação dos efeitos, não presentes da primeira.

4.4 Ação de descumprimento de preceito fundamental - ADPF

A EC 03/93 trouxe, além das novidades já mencionadas nos tópicos anteriores, a previsão da ADPF prevista no $\S 1^{\circ}$ do artigo 102 da CRFB/88 que tem por objeto evitar ou

\footnotetext{
II - o pedido, com suas especificações;

III - a existência de controvérsia judicial relevante sobre a aplicação da disposição objeto da ação declaratória.Parágrafo único. A petição inicial, acompanhada de instrumento de procuração, quando subscrita por advogado, será apresentada em duas vias, devendo conter cópias do ato normativo questionado e dos documentos necessários para comprovar a procedência do pedido de declaração de constitucionalidade.

${ }^{345}$ Sobre o tema, veja-se importante julgado do STF na Representação n. 1349, de relatoria do Min. Aldir Passarinho: Ementa: REPRESENTAÇÃO DE INCONSTITUCIONALIDADE. INCONSTITUCIONALIDADE NÃO RECONHECIDA DE INICIO PELA PROCURADORIA GERAL DA REPUBLICA AO OFERECER A REPRESENTAÇÃO. NÃO E DE SE CONHECER DA REPRESENTAÇÃO PARA DECLARAÇÃO DE INCONSTITUCIONALIDADE, NA CONFORMIDADE DO DISPOSTO NO ARTIGO 119, I, 'L' DA CONSTITUIÇÃO FEDERAL, COMBINADO COM O ART. 169, DO RI DO S.T.F., QUANDO O PRÓPRIO PROCURADOR GERAL DA REPUBLICA LOGO AO OFERECER A REPRESENTAÇÃO DECLARA INEXISTIR EIVA DE INCONSTITUCIONALIDADE NA LEI OBJETO DA ARGÜIÇÃO QUE LHE FOI DIRIGIDA POR TERCEIROS. LEI N. 7232, DE 29.10.84; DECRETO-LEI 2203-84; DECRETO 90.654 E DECRETO 90.756/84.
} 
reparar lesão a preceitos fundamentais, resultante de ato ${ }^{346}$ do poder público, bem como evitar ou reparar controvérsia constitucional sobre lei ou ato normativo federal, estadual ou municipal, incluídos inclusive os anteriores à CRFB/88.

Seu rol de legitimados contempla os mesmos previstos para a ADI e seus efeitos, em regra, são retroativos (ex tunc) e alcançam a todos (erga omnes) podendo, excepcionalmente, ter esses efeitos modulados.

Sobre o conceito do que se entende por preceito fundamental, FERNANDES (2013. p. 1166) assim traz:

\begin{abstract}
O que seriam os preceitos fundamentais? Primeiramente, devemos apresentar as correntes que debatem se os mesmos existem ou não dentro de nossa Constituição. Aqui, temos duas correntes sobre o tema:

$1^{\mathrm{a})}$ Corrente: defende que não existem preceitos fundamentais diferenciados na Constituição de outras normas constitucionais. Nesse sentido, toda a Constituição é um preceito fundamental por excelência. Essa corrente é eminentemente minoritária. $2^{\mathrm{a}}$ ) Corrente: afirma que, apesar de a Constituição ser uma norma fundamental, ou seja, ser fundamento de validade para as outras normas do ordenamento, existem preceitos fundamentais na mesma que se diferenciam de outras normas constitucionais (que não devem ser entendidas como preceitos fundamentais). Esta é a corrente majoritária e é inclusive a adotada pelo STF.
\end{abstract}

Tendo em conta a posição majoritária, pode-se dizer que o preceito fundamental está intimamente ligado às diretrizes da formação do Estado ou, na visão de FERNANDES (2013, p. 1166), “o núcleo ideológico constitutivo do Estado e da sociedade presente na Constituição formal.".

No tocante ao que seria exatamente esse núcleo, BULOS (2011, p. 1029) observa que os princípios da soberania, cidadania, a dignidade da pessoa humana, da livre iniciativa, do estado democrático, do juiz e do promotor natural, do contraditório, da impessoalidade, da legalidade, entre outros, integram esse arcabouço dos denominados preceitos fundamentais.

A ADPF possui duas espécies que podem ser visualizadas na Lei 9882/99, quais sejam: a ADPF por arguição autônoma e, quando originária do controle difuso, a arguição incidental ${ }^{347}$.

A ADPF possui caráter subsidiário, posto que sua utilização só deve ocorrer quando não houver outro meio cabível para reparar a lesividade, havendo inquestionável integração entre a ação em comento e as demais ações possíveis no controle concentrado e também no controle difuso, pois é subsidiária a elas, isto é, busca resguardar situações não alcançadas por estas

\footnotetext{
${ }^{346}$ Destaca-se que o STF vem admitindo a propositura da ADPF também para atacar decisões de juízes e tribunais que contrariem os preceitos fundamentais (Informativo do STF 810 no julgamento do MS 33586).

${ }^{347}$ Cf: BARROSO, Luís Roberto. O controle de constitucionalidade no direito brasileiro: exposição sistemática da doutrina e análise crítica da jurisprudência. São Paulo: Saraiva, 2012.
} 
ações, de forma muito mais ampla ${ }^{348}$.

\section{COMO SÃO JULGADAS AS ADIs}

Muitos autores fundados na teoria neconstitucionalista e na teoria substancialista do controle de constitucionalidade relacionam o controle à supremacia da Constituição e à defesa dos direitos fundamentais estampados em seu texto.

LENZA $^{349}$ (2015. p. 309) e MORAES (2008. p. 699) ${ }^{350}$ são exemplos de autores que identificam o controle de constitucionalidade como meio a garantir a supremacia constitucional no ordenamento jurídico e de seu núcleo axiológico fundamental.

Contudo, em 2013, Alexandre Araújo Costa e Juliano Zaiden Benvindo publicaram um completo, sistemático e provocativo estudo sobre as ADIs distribuídas e julgadas pelo STF no período compreendido entre 05 de outubro de 1988 a 31 de dezembro de 2012, intitulado: “A quem interessa o controle concentrado de constitucionalidade? O descompasso entre teoria e prática na defesa de direitos fundamentais ${ }^{351}$ ".

Naquela oportunidade os referidos autores buscavam investigar se o controle concentrado de constitucionalidade, "tal como hoje desenhado, tem efetivamente contribuído para a proteção dos direitos e garantias fundamentais e, portanto, para a consagração da democracia brasileira" (2013. p. 1).

Para responder ao tema-problema foram analisadas 4.727 ações, a iniciar da ADI $01 \mathrm{e}$ concluir com a ADI $4893^{352}$, apresentando ao final conclusão segundo a qual, "muito mais do

\footnotetext{
348 "Acreditava-se que a ADPF pudesse incorporar-se ao rol de procedimentos aptos à defesa dos direitos fundamentais, a exemplo do recurso constitucional alemão e do recurso de amparo mexicano, ditinguindo-se desses congêneres alienígenas pelo fato de possuir efeitos inter partes ou, no máximo, coletivos, tal como no Mandado de Segurança Coletivo, na Ação Civil Pública e na Ação Popular.

Todavia, não foi isso o que ocorreu. Na verdade, a lei aprovada no Congresso Nacional englobou os três modelos do controle concentrado alemão num único procedimento, quais sejam: a via principal, o incidente concreto e o recurso constitucional”. (CRUZ, 2004, p. 433).

349 “o órgão jurisdicional competente deve examinar a regularidade do processo legislativo, sempre tendo em vista a constatação de eventual afronta à Constituição, mormente, aos direitos fundamentais" (LENZA, 2015. p. 309).

350 "A ideia de controle de constitucionalidade está ligada Pa Supremacia da Constituição sobre todo o ordenamento jurídico e, também, à rigidez constitucional e proteção dos direitos fundamentais.” (MORAES, 2015. p. 699).

${ }^{351}$ Cf: Disponível em:

www.academia.edu/7832828/A_quem_interessa_o_controle_concentrado_de_constitucionalidade Acessado em 10 jan de 2016.

${ }^{352}$ A diferença apurada entre o número de ações analisadas e o número ordinário das ADIs "ocorre em virtude do sistema de processamento eletrônico, que tem possibilitado a autuação de processos nos quais, muitas vezes, não é apresentada uma petição inicial, seja porque não foi apresentado o documento ou porque foi apresentado documento diverso de uma inicial de ADI. Nesses casos, o número ficou tomado, mas não há um processo correspondente a ele (COSTA, 2013. p. 13).
} 
que defender os direitos e garantias fundamentais, o controle concentrado de constitucionalidade é um grande instrumento para a defesa de interesses corporativos, explicitando-se, assim, uma clara dissonância entre discurso doutrinário e prática judicial" (COSTA, 2013.p. 1).

Inspirados pela pesquisa acima, apresentamos aqui a análise realizada das decisões proferidas pelo STF nas ADIs julgadas entre o período compreendido entre $1^{\mathrm{o}}$ de janeiro de 2013 a 10 de novembro de 2015, buscando averiguar se a conclusão a que chegaram Alexandre Araújo Costa e Juliano Zaiden Benvindo permaneceram inalteradas.

Primeiramente há que se destacar que não se pretende aqui atualizar ou completar a pesquisa paradigma, isto porque tanto o recorte como a metodologia utilizada em nossa pesquisa é diferente daquela.

Os gráficos e tabelas a seguir apresentados foram construídos e nutridos com dados estatísticos obtidos no site ${ }^{353}$ institucional do STF organizados pelos próprios autores, sendo colhidas e sistematizadas as informações com o objetivo de avaliar o que a Corte vem julgado em sede de controle concentrado de constitucionalidade.

Também, foram realizadas consultas diretas às decisões prolatadas por meio de consulta ao banco de dados de jurisprudências ${ }^{354}$ do STF por meio de tag acompanhada de conectivo ${ }^{355}$ com o fim de evitar dispersão dos resultados.

Os pesquisadores compreendem que a metodologia utilizada poderá alcançar distorção no resultado obtido, entretanto, também acreditam que o universo analisado será capaz de trazer um comparativo razoável e que as distorções mínimas, se existirem, não terão o condão de trazer alterações substanciais ao resultado.

\subsection{Universo investigado}

Diante do recorte temporal definido, $1^{\circ}$ de jan de 2013 a 10 de nov de 2015, cumpre dimensionar a o universo a ser investigado, isto porque, ao STF são atribuídas tanto competências de Corte Constitucional $^{356}$ (art. 102, I da CRF/88) como de Suprema Corte (102,

\footnotetext{
${ }^{353}$ Cf: http://www.stf.jus.br/portal/cms/verTexto.asp?servico=estatistica\&pagina=acervoinicio

${ }^{354}$ Cf: http://www.stf.jus.br/portal/jurisprudencia/pesquisarJurisprudencia.asp

${ }^{355}$ A pesquisa se deu sobre os seguintes parâmetros: "inconstitucionalidade prox material" e "inconstitucionalidade prox formal".

${ }^{356} \mathrm{O}$ status de Corte Constitucional brasileira se difere daquela idealizada por KELSEN (2006. p. 135), pois além de não ser dedicada exclusivamente ao controle concentrado e abstrato de constitucionalidade também está integrada ao Poder Judiciário (art. 92, I da CRFB/88),
} 
III da CRFB/88), recursal (art. 102, II da CRFB/88) e originária (art. 102, I da CRFB/88) ${ }^{357}$.

Ainda que o objetivo deste trabalho esteja relacionado com o perfil dos julgados, diante do princípio da inércia da jurisdição ${ }^{358}$, se faz necessário também avaliar o perfil da entrada ${ }^{359}$ dos processos, com objetivo de traçar, desde logo, o cenário geral do universo a ser investigado.

Conforme gráfico a seguir, no período analisado, foram distribuídas 746 ações destinadas ao controle concentrado ${ }^{360}$, número este extremamente reduzido se comparado às demais competências do STF.

Gráfico 1: Distribuição no controle concentrado e demais competências.

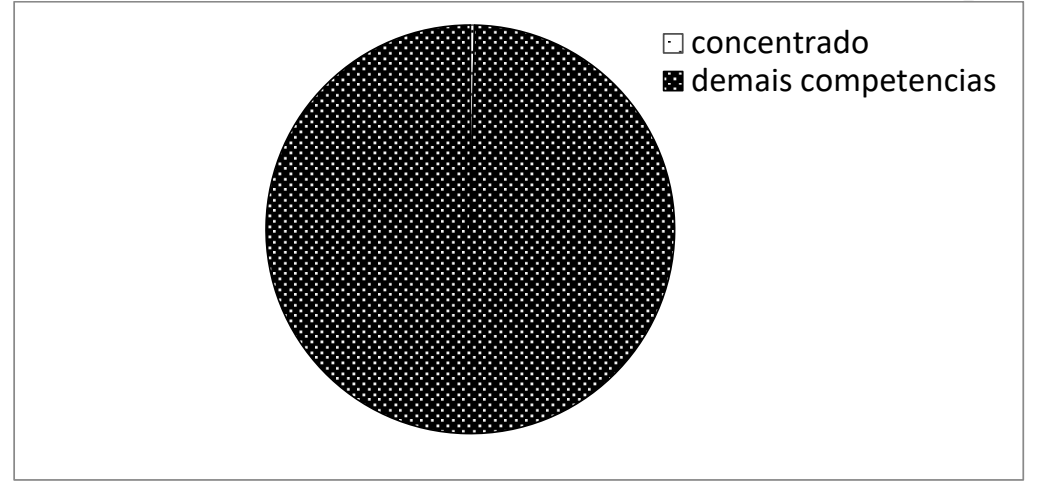

Fonte: Site do STF. Acessado em 10 nov 2015

Org. pelos autores

TABELA 1: Controle concentrado e demais competências

\begin{tabular}{cccc}
\hline Período & Concentrado & Demais competências & Total \\
\hline $2013-11 / 2015$ & $746-0,32 \%$ & $229.123-99,68 \%$ & $229.869-100 \%$ \\
\hline & Fonte: Site do STF. Acessado em 10 nov 2015 \\
Org. pelos autores
\end{tabular}

Diante dos dados coletados é possível afirmar que a competência de Corte Constitucional também atribuída ao STF é muito reduzida, 0,32\%, se comparada às demais competências constitucionalmente atribuídas que alcançaram a espantosa marca de 229.123 ações.

Dentro do universo analisado, controle concentrado, uma espécie se destaca por ser responsável por $92 \%^{361}$ das ações distribuídas no período sob exame, como se observa das

\footnotetext{
357 NERY JUNIOR (2004, p. 29-30) possui posicionamento diverso argumentando que "no atual sistema constitucional brasileiro, temos realmente uma Corte Constitucional Federal, consubstanciada no STF, conclusão que se extrai da competência que o legislador constituinte conferiu àquela corte de justiça."

${ }^{358}$ Art. $2^{\circ}$ do CPC.

${ }^{359}$ Sobre o tema conferir FALCÃO (2011).

${ }^{360}$ ADI, ADO, ADC e ADPF.

${ }^{361}$ Média aritmética simples de cada ano que compõe o período analisado.
} 
tabelas, anuais, a seguir colacionadas.

TABELA 2: Ações distribuídas em 2013.

\begin{tabular}{ccc}
\hline Período & Distribuída & Porcentagem \\
\hline ADI & 186 ações & $98 \%$ \\
ADO & 4 ações & $2 \%$ \\
ADC & - & $0 \%$ \\
ADPF & - & $0 \%$ \\
\hline
\end{tabular}

Fonte: Site do STF. Acessado em 10 nov 2015

Org. pelos autores

TABELA 3: Ações distribuídas em 2014.

\begin{tabular}{ccc}
\hline Período & Distribuída & Porcentagem \\
\hline ADI & 112 ações & $96 \%$ \\
ADO & 3 ações & $2 \%$ \\
ADC & 2 ações & $2 \%$ \\
ADPF & - & $0 \%$ \\
\hline
\end{tabular}

Fonte: Site do STF. Acessado em 10 nov 2015

Org. pelos autores

TABELA 4: Ações distribuídas 2015 (jan a nov).

\begin{tabular}{ccc}
\hline Período & Distribuída & Porcentagem \\
\hline ADI & 194 ações & $82 \%$ \\
ADO & 6 ações & $2 \%$ \\
ADC & 4 ações & $1 \%$ \\
ADPF & 43 ações & $15 \%$ \\
\hline
\end{tabular}

Fonte: Site do STF. Acessado em 10 nov 2015

Org. pelos autores

Diante do quadro é possível afirmar que a ADI é a espécie de ação do controle concentrado de constitucionalidade mais distribuídas no STF, alcançando, especialmente, no ano de 2013 quase a totalidade do número de ações destinadas ao controle concentrado, em virtude disto, a análise a ser desenvolvida irá se restringir apenas a esta espécie de ação, por ser quantitativamente mais relevante.

5.2 Análise quantitativa e qualitativa das ADI distribuídas/julgadas 
Na pesquisa paradigma, COSTA (2013. p. 24-25) identificou três portes de demandantes (grande, médio e pequeno), classificados conforme número de ADIs propostas entre o período de 1988 a 2012.

Compreende a primeira categoria, as associações e confederações sindicais; Governadores; PGR; e partidos políticos; a segunda categoria é formada apenas pelo Conselho Federal da OAB; e um terceiro grupo, de pequeno porte, formado pelos demais legitimados e os manifestantes ilegítimos.

Como se verificará na Tabela 5 a seguir, os resultados obtidos pelos autores desta pesquisa são semelhantes ao na pesquisa paradigma, que também identificou a presença de três grupos, porém, diferente da pesquisa de COSTA (2013) outro grupo se associou ao Conselho Federal da $\mathrm{OAB}$ se tornando de porte médio, sendo estes o grupo formado por pessoas manifestamente ilegítimas.

A justificativa da mudança de categoria atribuída a grupo formado por ilegítimos decorre da intensificação jurisprudencial do STF e da barreira criada pela "pertinência temática".

A pesquisa de COSTA (2015. p. 7) analisou vinte e quatro anos de ADI, entretanto a pertinência temática vindicada das entidades de classes de âmbito nacional iniciou-se em 1990, após o julgamento da ADI-MC 138, enquanto a das Confederações sindicais e dos governadores, em 1994, com o respectivo julgamento das ADI-MC 1151 e ADI 902, e por fim, a pertinência temática passou a ser exigida das Assembleias legislativas em 1995, com o julgamento da ADI 1307.

Há também que se destacar que a EC 45/04 ampliou o rol de legitimados por cuja pertinência temática é exigida, ampliando também, a possibilidade da declaração de ilegitimidade ativa por ausência de interesse processual.

Assim, temos que o reconhecimento da ilegitimidade na propositura de ADI foi sendo intensificado no tempo, repercutindo no aumento da média de ações distribuídas por autores posteriormente declarados ilegítimos, atualmente, corresponde a $6 \%{ }^{362}$ das distribuições.

No período analisado, as associações e representações sindicais estiveram presentes em 90\% das ADIs em que foram reconhecidas a ilegitimidade ad causam; o restante, compreendido

362 ADI 4967, ADI 4209, ADI 4660, ADI 3119, ADI 5235, ADI 3945, ADI 4554, ADI 4744, ADI 4569, ADI 5247, ADI 4371, ADI 4823, ADI 5048, ADI 4755, ADI 4876 ED-terceiros, ADI 4493, ADI 4561, ADI 4574, ADI 4443, ADI 4202, ADI 3913, ADI 4631, ADI 4940, ADI 5023, ADI 4892, ADI 4465, ADI 4840, ADI 4788 e ADI 4858 . 
em $10 \%$, figuraram no polo ativo pessoa jurídica, cooperativa ou pessoa física, todos ilegítimos.

TABELA 5: Legitimados e distribuição de ADIs.

\begin{tabular}{ccc}
\hline Autores & $2013-2015$ (jan-nov) & Categoria \\
Governadores & $28,0 \%$ & Grande \\
PRG & $23,2 \%$ & Grande \\
Partidos Políticos & $19,1 \%$ & Grande \\
Ilegítimos e confederação sindical & $16,7 \%$ & Grande \\
OAB & $6,0 \%$ & Médio \\
Mesa da assembleia & $5,2 \%$ & Médio \\
Presidente & $1,0 \%$ & Pequeno \\
Mesa da câmara dos deputados & $0,2 \%$ & Pequeno \\
Mesa do senado & $0,4 \%$ & Pequeno \\
\hline
\end{tabular}

Fonte: Site do STF. Acessado em 10 nov 2015

Org. pelos autores

Por outro lado, também se verifica que o grupo formado pelas associações e confederações sindicais é o que mais propôs ADIs, porém o grupo formado pelos Governadores é o grupo que obteve o maior número de sentenças de mérito proferida no período analisado, tal fato representa o descompasso entre inputs e outputs no sistema de controle concentrado de constitucionalidade e a restrição que a pertinência temática impõe ao primeiro grupo.

Gráfico 2: Decisão de mérito por legitimado no período de 2013-2015 (10 nov 2015)

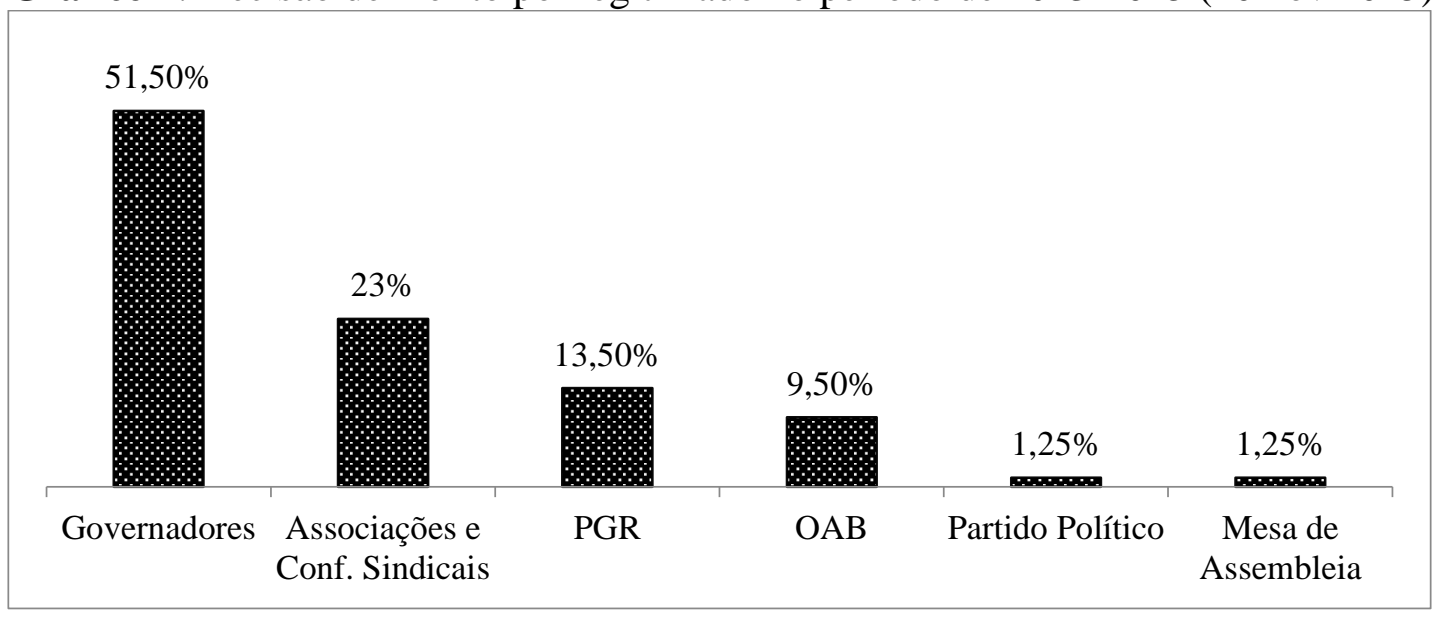

Fonte: Site do STF. Acessado em 10 nov 2015

Org. pelos autores 
5.3 Atos impugnados e a inconstitucionalidade material e formal

No período analisado não foram localizadas nenhuma sentença de mérito destinada a questionar Lei federal, porém, foram objeto de impugnação Emenda Constitucional, por meio das ADI 4425 e ADI 4337, e a Medida Provisória, pela ADI 2588, tendo os demais julgados se limitado as Leis Estaduais.

Gráfico 3: Normas impugnadas com julgamento de mérito

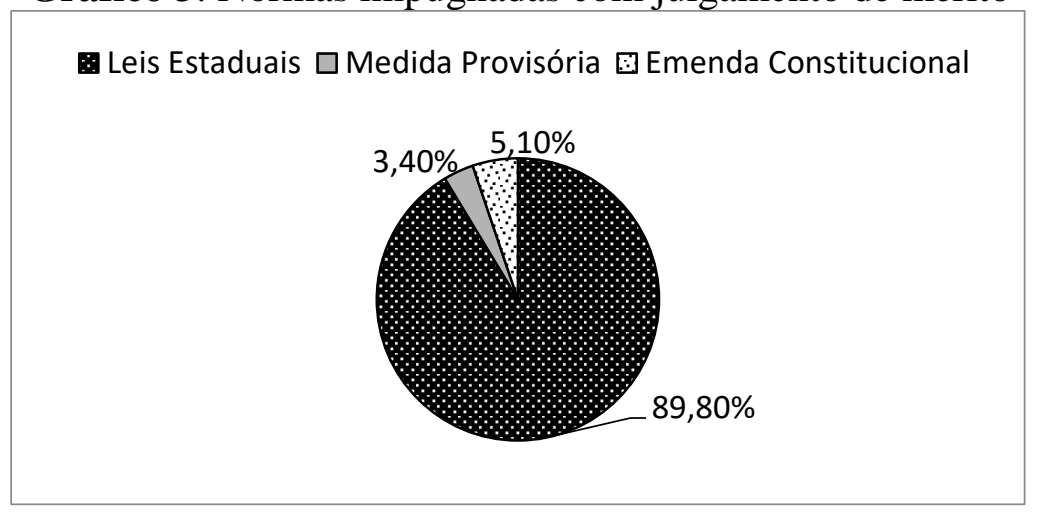

Fonte: Site do STF. Acessado em 10 nov 2015

Org. pelos autores

Observado que a esmagadora maioria das ADIs que possuem sentença de mérito refere-se a impugnações de leis estaduais é forçoso identificar que tal fato justifica o maior sucesso que o grupo formado por governadores tem em ver a apreciado o mérito de suas impugnações, direcionadas a leis estaduais.

Dentro das decisões de mérito proferidas pelo STF entre 2013 a 10 de nov. 2015, $76 \%{ }^{363}$ das matérias analisadas correspondiam ao exame da inconstitucionalidade formal ${ }^{364} \mathrm{e}$ em $24 \%{ }^{365}$ faziam referência a inconstitucionalidade material ${ }^{366}$.

Aproximadamente $86 \%$ das impugnações direcionadas a inconstitucionalidade formal foram julgadas procedentes ou parcialmente procedentes.

Gráfico 3: Normas impugnadas com julgamento de mérito - inconstitucionalidade formal

\footnotetext{
363 Parâmetro de pesquisa: "inconstitucionalidade prox formal".

364 ADIs: 5075(LE), 3926(LE), 4433(LE), 2699(LE), 4284(LE), 5163(LE), 2615(LE), 4792(LE), 4791(LE), 2255(LE), 3777(LE), 2124(LE), 2616(LE), 4643(LE), 3627(LE), 3223(LE), 2880(LE), 4203(LE), 4161(LE), 1440(LE), 4950(LE), 3075(LE), 1808(LE), 1509(LE), 1381(LE), 4276(LE), 2834(LE), 429(LE), 3564(LE), 2654(LE), 4007(LE), 4947(LE), 5020(LE), 510(LE), 2886(LE), 179(LE), 2818(LE), 2137(LE), 2960(LE), 3708(LE), 2198(LE), 2588 (MP), 4425 (EC), 4357 (EC) e 4372(LE).

365 ADIs: 3777(LE), 1440(LE), 4950(LE), 3075(LE), 1808(LE), 1509(LE), 251(LE), 2300(LE), 4279(LE), 429(LE), 4007(LE), 2588 (MP), 4425 (EC) e 4414 (LE).

366 Parâmetro de pesquisa: "inconstitucionalidade prox material".
} 


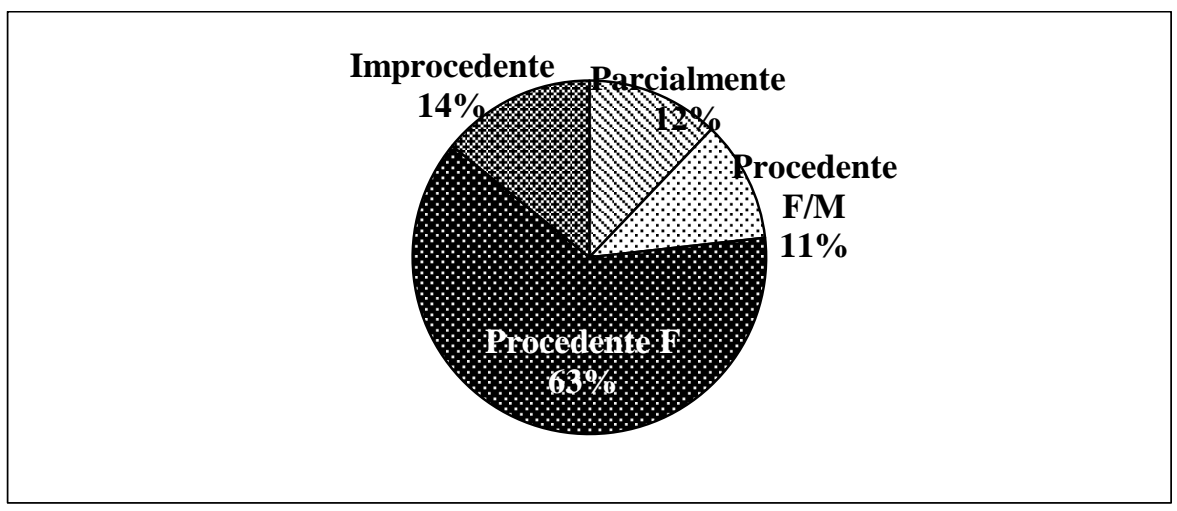

Fonte: Site do STF. Acessado em 10 nov 2015

Org. pelos autores

Observa-se que em apenas em $11 \%$ dos casos o STF reconheceu, ao mesmo tempo, a existência de inconstitucionalidade formal e material percentual menor que a própria improcedência dos pedidos atinentes à inconstitucionalidade formal, que alcançou $14 \%$ dos julgados.

Nas impugnações cuja inconstitucionalidade fazia referência à forma ${ }^{367}$, em $52 \%$ das oportunidades observou-se a inconstitucionalidade formal subjetiva por vício de iniciativa, contra $48 \%$ de inconstitucionalidades por vício formal orgânico.

Cumpre destaca que nos julgamentos de inconstitucionalidade por vício formal não há análise substancial da lei ou ato normativo impugnado, o julgamento se atém a vícios formais condizentes a subsunção à norma constitucional.

Segundo a teoria procedimentalista, o afastamento de lei ou ato normativo contaminado pelo vício formal serve à defesa das minorias, sendo reverenciado o respeito às formalidades constitucionais, que, em sua essência, serviria à garantia de direitos mínimos.

No período analisado, os julgamentos de impugnações sobre o conteúdo de Leis ou atos normativos frente ao texto constitucional se mostraram reduzidos, apenas catorze julgamentos. Diferente do anotado acima quando analisado o julgamento do reconhecimento concomitante de inconstitucionalidade formal e material pelo STF sobre o prisma formal, no viés material, em virtude da base menor (14), os julgamentos que reconheceram a inconstitucionalidade simultânea representam alto índice, alcançando $43 \%$ dos julgados.

Gráfico 4: Normas impugnadas com julgamento de mérito - inconstitucionalidade material

367 "Por sua vez, a inconstitucionalidade formal propriamente dita decorre da inobservância do devido processo legislativo. Podemos falar, então, além de vício de competência legislativa (inconstitucionalidade orgânica), em vício no procedimento de elaboração da norma, verificado em momentos distintos: na fase de iniciativa ou nas fases posteriores". (LENZA, 2015. p. 298) 


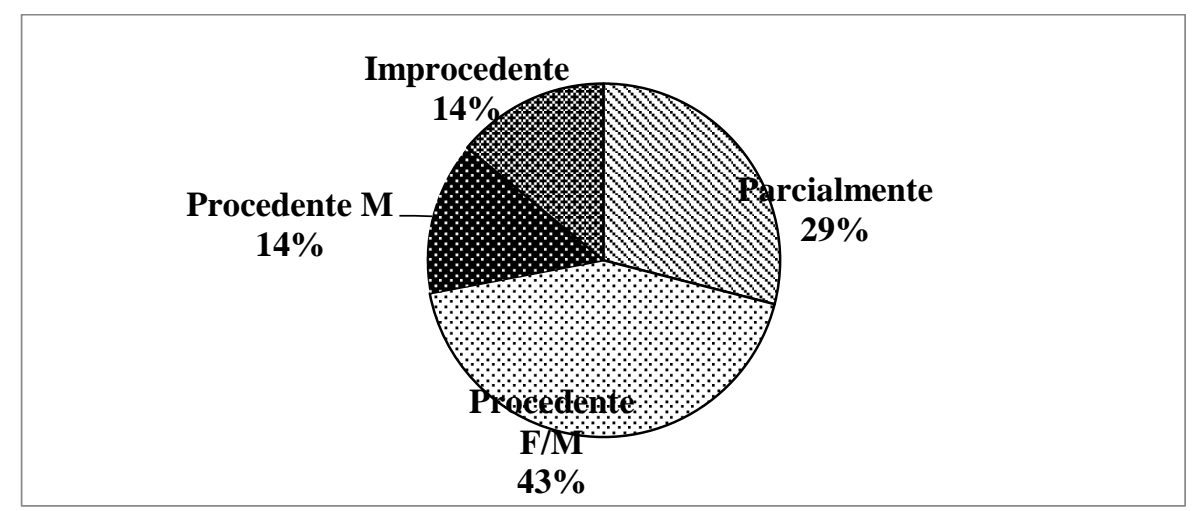

Fonte: Site do STF. Acessado em 10 nov 2015

Org. pelos autores

Dentre as catorze ADIs selecionadas, cujo julgamento se deu por meio do exame substancial da Lei ou ato normativo impugnado, em doze (86\%) delas foram levados ao STF discussões relacionadas a interesses de caráter corporativo, algo que já era previsível a partir da seleção de legitimados em 1988 (COSTA, 2013. p. 27).

Em apenas duas (14\%) ocasiões os direitos fundamentais foram objeto de análise, a saber: ADI 4425, proposta pela CNI (Confederação Nacional das Indústrias) que impugnou parcialmente a EC 62/09 e ADI 1880, proposto pelo Governador do Estado do Amazonas, que impugnou o art. $6^{\circ}$ do ADCT da Constituição Estadual do Amazonas.

Contudo há que se observar que, para ambos os legitimados citados logo acima, constitui elemento de condição da ação a demonstração de pertinência temática, por não pertencerem à categoria de legitimados universais.

Sobre a pertinência temática, o STF já se posicionou a respeito reconhecendo sua necessidade para determinados grupos de legitimados em virtude dos interesses específicos de cada categoria ou região a que estão atrelados (ADI $4537^{368}$ ).

\footnotetext{
368 1. Trata-se de ação direta de inconstitucionalidade, com pedido de liminar, proposta pela Confederação Nacional dos Trabalhadores Metalúrgicos - CNTM, contra as Leis Ordinárias no 4.503, de 10/09/1992, e 4.859, de 27/08/1996, ambas do estado do Piauí, bem como contra o Decreto no 9.591, de 21/10/1996. 2. Em síntese, postula a Confederação que seja reconhecida a violação ao art. $155, \S 2^{\circ}$, XII, "g" da CF/88, alegando que, pelos atos normativos impugnados, foram instituídos benefícios fiscais relativos ao ICMS, sem prévio convênio interestadual autorizador. 3. Diante da relevância da matéria, o Ministro Joaquim Barbosa submeteu o feito ao rito do art. 12 da Lei $n^{\circ}$ 9.868/1999. 4. Em suas informações, a Assembleia Legislativa do Estado do Piauí alega, preliminarmente, a ilegitimidade ativa da requerente, em razão de suposta ausência de pertinência temática. Quanto ao mérito, aduz que "não cuidam tais normas de isenção de imposto, in casu, ICMS, mas sim, de dispensa do recolhimento realizado pela empresa beneficiária, desde que se enquadre nos moldes da lei", de modo que seria desnecessária a existência de convênio prévio do CONFAZ. 5. O Advogado-Geral da União, de modo preliminar, sustenta a ilegitimidade ativa da Confederação autora, em razão da inexistência de comprovação da pertinência temática. No mérito, expressa o entendimento de que as leis impugnadas instituíram espécie de benefício fiscal relativo ao ICMS, de modo que sua instituição apenas poderia se dar consoante o procedimento previsto no art. $155, \S 2^{\circ}$, inciso XII, "g" da CF/88, razão pela qual o pedido formulado seria precedente. 7. Já a ProcuradoriaGeral da República exarou parecer no sentido do conhecimento da ação (reconhecendo, portanto, a legitimidade ativa da Confederação) e da procedência do pedido. 8. É o relatório. Passo a decidir. 9. Tenho que a ação não pode ser conhecida. 10. O artigo 103, inciso IX, da Constituição Federal de 1988 atribui às confederações sindicais a
} 
Assim, mesmo presente nas duas ADIs supracitadas a abordagem dos direitos fundamentais, a defesa se manifestou em proveito de determinada categoria ou região, sendo portanto, patente o interesse corporativo do uso da ADI, mesmo nos casos em que foram analisados direitos fundamentais.

\section{CONSIDERAÇÕES FINAIS}

O controle de constitucionalidade no Brasil tem origem na primeira Constituição da República de 1891, fundamentada na matriz americana de controle difuso e concreto.

O controle concentrado e abstrato constitucional foi realmente inserido no ordenamento jurídico com a EC 16/65, passando a existir no Brasil o controle híbrido de constitucionalidade.

Duas teorias sobre o controle de constitucionalidade se desenvolveram sob o manto do neoconstitucionalismo, a teoria procedimentalista e a teoria substancialista, em ambas é encontrada a defesa da supremacia e efetividade constitucional, bem como dos direitos mínimos.

Mesmo o controle concentrado e abstrato de constitucionalidade tendo representando apenas $0,32 \%$ das ações dirigidas ao STF, no período compreendido ente 2013 a 10 de novembro de 2015, é evidente a sua grande importância diante do potencial impacto jurídico que pode causar, em virtude dos efeitos das decisões que tem eficácia erga omnes e, em regra, ex tunc.

O acesso ao controle concentrado e abstrato de constitucionalidade se opera por meio de legitimados enumerados na CRFB/88 para quem é colocada a disposição ações

\footnotetext{
legitimidade ativa para a propositura de ações do controle concentrado de constitucionalidade. Entretanto. interpretando tal dispositivo, o Supremo tem pacificamente assentado a necessidade de demonstrar não apenas a natureza jurídica exigida pela Constituição, mas também a necessária relação de pertinência temática, isto é, a existência de correlação específica entre o objeto do pedido de declaração de inconstitucionalidade e os objetivos institucionais da Confederação autora, bem como a repercussão direta da norma impugnada na classe representada pelo respectivo ente autor. Isso porque, ao contrário de outros legitimados, cuida-se de entidade de direito privado, vinculada essencialmente à proteção dos interesses específicos da categoria representada. 11 . Nesses termos, embora a requerente busque demonstrar na inicial a pertinência temática exigida, entendo que, no caso, o requisito inexiste. Isso porque a argumentação expendida aponta como fundamento da pertinência temática a eventual diminuição dos empregos da classe representada, os metalúrgicos, fato que decorreria da guerra fiscal incentivada pela norma impugnada. Desse modo, tenho que, nessa hipótese, a norma impugnada não se dirige especificamente aos metalúrgicos, tampouco impacta seus interesses de forma direta. Não há, portanto, pertinência temática entre os propósitos da Confederação, de defesa dos interesses da categoria, e o deferimento de benefício de ICMS. 12. Note-se que nesse mesmo sentido decidiu o Min. Marco Aurélio na ADI $\mathrm{n}^{\circ}$ 4.721, caso bastante semelhante ao aqui julgado. 13. Assim, nos termos dos arts. $4^{\circ}$ da Lei $n^{\circ} 9.868 / 1999,38$ da Lei $n^{\circ} 8.038 / 1990$ e $21, \S 1^{\circ}$ do RISTF, nego seguimento à presente ação direta. Publique-se. Brasília, 29 de outubro de 2014. Ministro Luís Roberto Barroso Relator.
} 
predeterminadas que poderão ser manejadas conforme objetivo e espécie normativa a ser impugnada.

Dentro das ações disponíveis, ADI, ADO, ADC e ADPF, a mais acionada é a Ação Direta de Inconstitucionalidade responsável, em média, por $92 \%$ das ações distribuídas no controle de constitucionalidade concentrado e abstrato no período do recorte, possuindo como característica o fato de sua imensa maioria tratar de impugnações a leis estaduais.

Observando o ingresso de ADIs no período já relatado é possível identificar que o grupo que mais propôs ADIs é formado por associações e confederações sindicais, porém, o grupo que mais obteve êxito em ter o mérito da ação analisada é composto por governadores.

A maior parte das ADIs julgadas pelo STF relacionam-se a inconstitucionalidade formal, $76 \%$, havendo grande êxito nas declarações de inconstitucionalidade desta, $86 \%$, tanto formal subjetiva por iniciativa, 52\%, como formal orgânica $48 \%$.

Apenas $24 \%$ dos julgamentos das ADIs propostas no lapso proposto analisaram o mérito substancial constitucional sendo atestado que, em todas as oportunidades, a ação proposta esteve voltada a atender os interesses corporativos do grupo de legitimados/autores, sendo crível que em apenas $14 \%$ dessas foi realizado alguma análise sobre os direitos e garantias fundamentais.

Por derradeiro, se torna forçoso concluir que o desenho constitucional apresentado pelo constituinte de 1988 afasta a aplicação fática da teoria substancialista do controle constitucional concentrado e abstrato brasileiro, pois vem servindo a grupos privilegiados que receberam prerrogativas no texto constitucional.

\section{REFERÊNCIAS}

BARBI, Celso Agrícola. Evolução do contrôle da constitucionalidade das leis no Brasil. In: CLÈVE, Clèmerson Merlin (Org.); BARROSO, Luís Roberto (Org.). Doutrinas Essenciais: direito constitucional. Defesa da Constituição: aspectos gerais do controle de constitucionalidade, controle difuso de constitucionalidade, controle concentrado de constitucionalidade. Revista dos Tribunais: São Paulo, 2011. p. 87-101;

BARBOSA, Estefânia Maria de Queiroz; KOZICKI, Kátia. Democracia procedimental e jurisdição constitucional. Anais do XVI Congresso Nacional do CONPEDI. Belo Horizonte. Florianópolis: Boiteux, 2007. p. 6745-6765;

BARBOSA, Rui. O Direito do Amazonas ao Acre Septentrional. Rio de Janeiro: Jornal do Comércio, 1910; 
BAROUCH, Ricardo Ferreira. O controle concentrado de constitucionalidade das normas no direito brasileiro: evolução da jurisdição constitucional. In: Revista do Tribunal de Contas do Estado de Minas Gerais. Ano 1, n. 1 (dez. 1983- ). Belo Horizonte: Tribunal de Contas do Estado de Minas Gerais, 1983. p.87-102.

BARROSO, Luís Roberto. Neoconstitucionalismo e constitucionalização do Direito: o triunfo tardio do Direito Constitucional no Brasil. Jus Navigandi, Teresina, ano 10, n. 851, 1 nov. 2005. Disponível em: https://jus.com.br/artigos/7547/neoconstitucionalismo-e-constitucionalizacaodo-direito

Acessado em: 19 de jan de 2016;

BARROSO, Luís Roberto. O Controle de Constitucionalidade no Direito Brasileiro: exposição sistemática da doutrina e análise crítica da jurisprudência. São Paulo: Saraiva. 2012;

BONAVIDES, Paulo. Curso de direito constitucional. São Paulo: Malheiros, 2008;

BULOS, Uadi Lammêgo. Curso de Direito Constitucional. São Paulo: Saraiva, 2011;

CAPPELLETTI, MAURO. O controle judicial de constitucionalidade das leis no direito comparado. Porto Alegre: Fabris, 1984;

CARVALHO, Kildare Gonçalves. Direito Constitucional: teoria do Estado e da Constituição. Direito constitucional positivo. Belo Horizonte: Del Rey, 2010;

COSTA, Alexandre Araújo; BENVINDO, Juliano Zaiden. A quem interessa o controle concentrado de constitucionalidade? O descompasso entre teoria e prática na defesa de direitos fundamentais. Disponível em: www.academia.edu/7832828/A_quem_interessa_o_controle_concentrado_de_constitucionali dade Acessado em 10 jan de 2016;

CRUZ, Álvaro Ricardo de Souza. Jurisdição constitucional democrática. Belo Horizonte: Del Rey, 2004.

DALlARI, Dalmo de Abreu. A Constituição na vida dos povos: da idade média ao século XXI. São Paulo: Saraiva. 2010;

DANTAS, Ivo. O Valor da Constituição: do controle de constitucionalidade como garantia da supralegalidade constitucional. Rio de Janeiro: Renovar, 2001; 
DWORKIN, Ronald. O império do direito. Trad. Jefferson Luiz Camargo. São Paulo: Martins Fontes, 2007;

ELY, John Hart. Democracia e desconfiança: uma teoria do controle judicial de constitucionalidade. Trad. Juliana Lemos. São Paulo: Martins Fontes, 2010;

FALCÃO, Joaquim. CERQUEIRA, Pablo de Camargo. ARGUELHES, Diego Werneck. I Relatório Supremo em números: o múltiplo Supremo. Fundação Getúlio Vargas. 2011. Projeto Supremo em números. Disponível em: <http://www.fgv.br/supremoemnumeros/relatorios/i_relatorio_do_supremo_em_numeros_0.p df.>. Acesso em 12 jan. 2016.

FERNANDES, Bernardo Gonçalves. Curso de Direito constitucional. Rio de Janeiro: Lumen Juris, 2013;

GILISSEN, John. Introdução Histórica ao Direito. Fundação Calouste Gulbenkian: Lisboa, 2008;

KELSEN, Hans. Teoria Pura do Direito. São Paulo: Martins Fontes, 2006;

LIMA, Augusto Carlos Rocha de. História do controle de constitucionalidade de atos normativos: precedentes e definição da sua concepção moderna. Revista de Direito Constitucional e Internacional, São Paulo, ano 17, n. 66, jan-mar, 2009, p. 89-120;

LENZA, Pedro. Direito Constitucional esquematizado. São Paulo: Saraiva. 2015;

MARINONI, Luiz Guilherme; MITIDIERO, Daniel; SARLET, Ingo Wolfgang. Curso de direito constitucional. São Paulo: Revista dos Tribunais, 2012;

PONTES DE MIRANDA, Francisco Cavalcanti. Comentários à Constituição de 1967 com a emenda no 1 de 1969. São Paulo: Revista dos Tribunais, 1970;

MENDES, Conrado Hüber. Controle de constitucionalidade e democracia. Rio de Janeiro: Elsevier, 2008;

MENDES, Gilmar Ferreira. Controle de constitucionalidade. In: MENDES, Gilmar Ferreira; COELHO, Inocêncio Mártires; BRANCO, Paulo Gustavo Gonet. Curso de direito 
constitucional. São Paulo: Saraiva, 2009.

PAGANELlA. Carlos Roberto Lima. As bases teóricas do controle difuso de constitucionalidade e suas competências para exame e rejeição no Brasil. 2007. $256 \mathrm{f}$. Dissertação (Mestrado em Direito) - Universidade Federal do Rio Grande do Sul, Porto Alegre, 2007.

PALU, Oswaldo Luiz. Controle de Constitucionalidade: conceitos, sistemas e efeitos. São Paulo: Revista dos Tribunais. 2001.

POLETTI, Ronaldo. Controle da constitucionalidade das leis. Rio de Janeiro: Forense, 2001.

SAMPAIO. Teoria da Constituição e dos Direitos fundamentais. Belo Horizonte: Del Rey. 2013;

TREVISAN, Thiago Valentim; AMARAL, Sérgio Tibiriçá. O caso Marbury contra Madison e a origem do controle difuso de constitucionalidade. Revistas eletrônicas da Toledo Presidente $\begin{array}{lllll}\text { Prudente. } & \text { v. 5, 2009.Disponível em: }\end{array}$ http://intertemas.unitoledo.br/revista/index.php/ETIC/article/viewFile/2586/2274 Acessado: $10 \operatorname{dez} 2015$.

\title{
CONTROL CONCENTRATE CONSTITUTIONALITY AND DEFENSE OF
}

\section{CORPORATE INTERESTS: analysis of ADIs in 2013 to 10 November 2015}

\begin{abstract}
The judicial review is being justified in academia as a means to guarantee the rights of minorities against interests of the majority expressed in violating laws of fundamental rights, however, currently, decisions made by the Supreme Court in headquarters concentrate constitutionality control, not come keeping correspondence with the mentioned theory guarantor because reverberate corporate interests of privileged groups, sometimes unrelated to fundamental rights. Identified the problem, went to the hypothesis that the current constitutional design addressed to judicial review promotes and is aimed, in fact, the corporatist rights protection, and this fact is reflected in the decisions rendered by the Supreme Court. To develop the hypothesis were carried out bibliographical studies on the subject, initially disbelieving the origin of arrays of judicial review and its development in Brazil, through the presentation of proceduralists and substantialist theories of judicial review and species of direct action
\end{abstract}


aimed at the STF in concentrated control and abstract laws or normative acts. In order to evaluate the hypothesis we were also collected and analyzed information data contained in the official STF site in the period between 2013 to November 10, 2015, and, finally, confirmed that today the constitutionality of concentrated control design serves the corporatist interests of certain groups.

Keywords: Concentrate controls. Corporatist interests. Substantial theory. 